\title{
Self-assessment Practices: an empowering Tool in the teaching and learning EFL Processes
}

Edgar Orlando Rodríguez Ochoa

\begin{abstract}
Evaluating the students' language learning process requires a lot of analysis and reflection. Although some research has been conducted to observe the way teachers use assessment practices in diverse educational contexts, I consider there needs to be more research in order to examine how assessment practices are carried out in our educational context. This article presents a pedagogical project carried out in a higher education institution with EFL learners. It focuses on the implementation of self-assessment practices conducted in the context of the project followed by some preliminary results that I have encountered.
\end{abstract}

Key Words: Assessment Practices, Listening Practices, Evaluation, Self Assessment Practices.

\section{Resumen}

La evaluación del proceso de aprendizaje de los estudiantes requiere un análisis exhaustivo y permanente reflexión. Aunque se han realizado algunas investigaciones con miras a determinar la manera cómo las prácticas de evaluación se desarrollan en varios contextos educativos, considero que debe haber más investigación enfocada a las practicas de evaluación en nuestro contexto educativo. Este artículo presenta un proyecto pedagógico que se llevo a cabo en una institución de educación superior con estudiantes de Inglés como lengua extranjera. Se centra en la implementación de prácticas de auto evaluación aplicadas en el contexto del proyecto seguido por resultados preliminares encontrados.

\footnotetext{
* Received: 02-04-07/Accepted 09-08-07
} 


\section{Introduction}

It is not a secret that evaluation plays a crucial role in all areas of knowledge and it is the tool teachers have to measure performance and quality. Specifically in the language education field, this issue is not less important. In fact, a lot of research, time and ideas have been spent in order to make the evaluation procedures more reliable and valid so that both teachers and students take real benefit from them and complement their process of learning and teaching.

In the enormous attempt to guarantee a proper method to evaluate our learners, some researchers have claimed for new alternatives so as to make the evaluation process more adjusted to the learners' needs rather than to the records they get from scores. Assessment practices, therefore, have emerged as an option in the search of such alternatives. Different from tests, these practices are aimed to evaluate the entire process students carry out. In spite of the fact that the results obtained in exams might be an important part in the learning process, assessment practices are more centred on evaluating how students develop their learning process, and how it alters the results they might obtain.

In the case of English as a Foreign Language, and more exactly, in the development of the listening skills, the use of self-assessment practices may become a very important resource in order to promote real interaction between the students and the process they are developing. Perhaps, through the implementation of this tool, both teachers and students could achieve a much deeper recognition of the weaknesses and strengths they have in the complex process of teaching and learning English.

\section{Rationale}

Having in mind the focus of self-assessment practices and the advantages they may bring to the development of the listening skills, I decided to implement those practices in a specific group of learners with the purpose of analysing and documenting the results such implementation could have. One of the reasons that encouraged me to develop this project was the necessities of my pupils. On the one hand, because when they started to study English, some of them erroneously believed that their teachers would be the only ones responsible for the success or failure of their learning process. On the other hand, because undoubtedly evaluation needs to be directed towards an adequate integration of the process learners are following, the methodologies teachers use, and the results obtained during the entire teaching and learning period. 
Another aspect which could justify the application of this project is the one related to the concept of "evaluation" that teachers, coordinators and even students need to deal with. More than classifying a student in good or bad, or grading exams, evaluation should integrate all aspects that make part of the learning and teaching process -exams, teachers' performance, students' performance, strengths, weaknesses, among others- . Additionally, evaluation should look for solutions and alternatives to cope with the concerns that could appear in the development of those processes. In other words, evaluation cannot be just a "picking up papers" procedure, it also needs reflection upon the methodology that some teachers utilize and the effectiveness that such methodology could have on the students. Self-assessment practices, hence, should be a space in which reflection becomes the most important aspect to be considered in the hard process of learning English as a foreign language.

\section{Context}

The project was developed at the Languages Centre of the Universidad Pedagógica Nacional. This institution offers free courses of English, French and German as foreign languages, and any person who is interested in learning them can have access to those courses. The program is divided into six levels (Basic I, Basic II, Intermediate I, Intermediate II, Advanced and Conversation) and each of them is one semester long. The groups are conformed by approximately 25 students in the basic levels and 18 students in the higher ones (Intermediate I-II, advanced and Conversation). With respect to the evaluation system, it is a mixture between the class performance and the scores students obtain from the exams, being the latter aspect much more important than the first one. Due to the fact that the coordinators and the administrative staff have attempted to be as fair as possible in the design and the application of the tests, some complaints have been received from the students since they believe those tests do not really evaluate what they have studied and learnt throughout the process ${ }^{1}$. The class performance, the second aspect that is considered in the evaluation procedure, is up to the teacher and is greatly marked by complementary activities and tasks that are designed by the teacher. The most common ones are presentations, written compositions, reading controls and quizzes.

1 This information was collected from feedback sessions that are usually conducted after the students present the exams. 
Even though the teachers do their best to provide students with the most appropriate and fairest evaluation techniques, there are some issues that should be considered. One of them is related to the level of participation students have on their evaluation process. It is quite important that pupils are aware of their strengths and weaknesses and work, together with the teachers' help, on coping with the concerns they may encounter throughout their learning process. Furthermore, teachers should know what goes on, and how effective their methods to teach are so as to promote a complementary reflection process between teachers and students.

Besides the aspects that I have mentioned above, I consider the development of the students' learning process as a key point for the implementation of this study. Undoubtedly, when students are involved in the process of learning a foreign language, they need to be conscious about the importance of being active participants, that is to say, not only is the teacher the one who tells them what difficulties or strengths they have, and even less the only one who knows what needs to be reinforced. On the contrary, I strongly think that they should be deeply conscious about how their learning process advances and what they can do in order to cope with the weaknesses found.

Taking into consideration the importance of implementing self assessment practices in the development of the EFL listening skills, the application of these procedures emerges as the way students could become participative agents in their learning process, and reflection and collaborative work would finally be the centre of an adequate teaching-learning EFL process.

\section{A Brief Review of the Literature}

As any other piece of research, my project counts on valid theoretical support which has been carefully selected, read and related to the research questions and objectives that I have posed. Likewise, the constructs I worked with are mostly related to the definition of assessment practices, listening practices, and some types of assessment procedures as well as the importance of using self-assessment practices.

\section{Listening Practices}

Nowadays, the listening practices are focused on the comprehension of the material provided in the sessions. However, students may find it difficult to perform some of the exercises conducted, and therefore they may feel frustrated when listening and understanding the material they are exposed to. 
With the purpose of improving the way listening skills development is conducted, Boyle (1993) provides the field with an interesting perspective of applying new listening comprehension tasks. According to her, one of the main issues that should be considered in the activities conducted has to do with the selection of the material. She states that such material should be appealing for the students so as to promote an active participation in the class. Perhaps, through the use of those "appealing materials", the students can enjoy much more the process of listening EFL material, and of course, take much more advantage of what is done in the exercises conducted.

Another author who is important in the definition of listening practices is White (1998). Basically, he contrasts the way some of them are developed and the possible mistakes they might have for students' learning process. White points out that the students do not have the opportunity to listen to the material very much. It means that the time spent in the activities is designed to discuss the answers or do some post-listening activities such as speaking interventions or written compositions. Nonetheless, White claims for more reflection upon the process of comprehension itself. In other words, both the students and the teachers need to spend more time in analysing the good and bad points they are facing process of teaching and learning EFL.

It is interesting to examine the two perspectives Boyle and White explain throughout their works. Boyle, on the one hand, is focused on the material presented for the sessions. We, as teachers, should understand that the process of assimilating foreign audio-recorded material is not easy; what is more, many of our students find it very difficult to catch what those speakers say, and what the main idea of such material is. This is the reason why we need to be very careful with the selection of the material provided and with the design of the activities. Not only is the objective to "have students listen to something", it is also indispensable to take care of things like the pace of the speakers, the accent, the speed of the material, and obviously, the class of material which is going to be presented to the students.

On the other hand, White is more concentrated on the process of comprehension. It is very important to observe and analyse whether we actually make our students develop their comprehension process or we just face them with something they do not understand. White claims for exercises in which students actually have the opportunity to work on such understanding process, 
and I consider it as an important aspect so as to guarantee effectiveness and an adequate follow up of the listening comprehension process.

\section{Assessment Practices}

In this construct, I will describe the most relevant types of assessment practices so as to shed light on the way I will use them in the implementation of my project. One author who I would like to cite is Cohen (1994). Assessment, according to him, plays an important role in processes of learning language and ought to be included in the procedures of evaluating both the students' language performance and their EFL learning process. In fact, he differentiates very clearly the applications of tests and other ways to assess performance. Likewise, Cohen deals with a concept of evaluation quite different from the one we are used to having. To begin with, he states that formal tests or some other quantitative methods of measuring do not show completely how much the students have learnt; thus, something else should be included, and assessment practices could be that "something". Another aspect which is crucial to consider is the one related to the valuable support teachers obtain from the application of assessment practices. Cohen points out that the inclusion of these practices gives teachers a clearer view about the actual students' learning process. However, it would be worth to clarify that assessment is not a unique concept. There are different types of assessment which deal with different characteristics as well as purposes. Among the most important ones, we find the formative and summative assessmen, the performance based assessment and the selfassessment practices. Having in mind the essence and characteristics of my study, I consider it is more relevant to define the latter type in order to count on a solid definition regarding this construct since this is the one which is focused on what actually occurs in the process students carry out..

\section{Self-assessment Practices}

O'Malley and Valdez (1996) identify different functions of these kinds of practices in the EFL learning process. One of them has to do with the importance of encouraging responsibility to the learners. As defined by the authors, selfassessment promotes critical thinking and involves students directly in their process of learning. That means, not only is the teacher responsible for his/her students' performance of the target language; they should be participating actively in such procedure so as to become critical and look for adequate solutions to the constraints encountered. Additionally, they remark that self- 
assessment might "help both teachers and students become aware of students' attitudes, strengths and weaknesses." (pg 100).

O'Malley and Valdez also emphasize the use of portfolios in self-assessment practices. In their opinion, these practices would be misused if this instrument were not taken into account. Through the use of portfolios, students can monitor their progress as well as the advance they obtain in the activities conducted. In other words, by using portfolios and being able to reflect on their own process, students will see an actual learning process, and will take into account that the teacher is not the only one involved in the teaching-learning process. The definition provided by O'Malley and Valdez is an important view about how to use self-assessment practices properly, and know what implies to implement them in the classrooms. Moreover, it is evident the fact that self-assessment practices should play a very important role in our practices since they might help students do real reflection procedures in their language learning process. Finally, it is worth to say that the use of self assessment practices might facilitate teachers to obtain more valuable feedback on their EFL learning process as long as it can give us more tools to improve the design of the activities we plan to develop our sessions.

\section{Learner-centred Listening Assessment}

The final construct of my project is based on listening assessment practices. Regarding this construct, Coombe and Kinney ${ }^{2}$ present an interesting concept of assessing the development of the students' listening skills. Learner-Centred Listening Assessment highlights the lack of exploration that assessment focused on learners' needs is currently facing. According to the authors, the learnercentred approach is directed to reach actual feedback and interaction between teachers and students. Unfortunately, some listening practices merely deal with the process of understanding the material used. However, much more should be done so that both teachers and students actually reflect upon their process of teaching and learning. It means, both of them need to provide and receive feedback on what happens in the conduction of the listening activities. The use of self assessment practices in the development of listening skills, for this reason, could enhance the use of adequate reflection procedures so as to obtain more solid evidence in the on-going process of understanding EFL material.

2 The year of the publication of the article is not stated in the bibliographic information. 


\section{The Implementation of the Project}

After having defined the key theoretical concepts which supported this study, it is important to describe carefully the development of the project. This study is aimed at seeing the way a determined group of learners perceive the implementation of some listening self-assessment practices. Based on that purpose, this project lies on the following research questions:

- What does the implementation of listening assessment practices tell us about the students' understanding of audio-recorded material?

- How do students perceive the implementation of self-assessment listening practices in their understanding of audio-recorded material?

\section{Type of Study}

Due to the characteristics of the intervention, it seems to me that the type of study that better matches the frame of my research project is action research. Cohen and Manion (1994) define action research as "a short scale intervention in the real world with the purpose of examining the effects of that intervention"; similarly, in 1994 the same authors stated that action research takes into account situational, collaborative, participatory and self-evaluative aspects. Considering that my project deals with these characteristics, I consider that action research, in this case, fits perfectly in the aim, the objectives and the questions that I have stated in order to develop this study. Furthermore, it is important to highlight that when action research is used to conduct a research project, a reflective cycle should also be followed. It consists of taking the professional practice as a point of departure for promoting reflection and reaching a much more complete professional development. In my personal case, I would affirm that my study began the reflective cycle by digging into my students' perceptions on the listening practices and identifying the problems they had; then, it continued with the design of adequate activities in order to solve such difficulties and ended up in the analysis and evaluation of the effects of those activities in the participants' process of understanding EFL recorded material.

Another author that gave me valuable tools and support to select the type of study was Bell (1987). She states that "action research is not a method or technique; it is an approach which has proved to be particularly attractive to educators because of its practical solving-problem emphasis." (p. 8). Having in mind that my project precisely lies on a problem encountered, I think it is 
very important to focus the development of the project on the solution of that concern and on the analysis of the results emerged after the application of the activities.

\section{The Participants}

The activities were applied to one entire course of 21 pupils studying at a basic level. Their ages were between 18 to 30 years old and they had already taken classes in the program. The class consisted of seven men and fourteen women. Most of the participants had a job or were university students, and their reason to study English was basically better job opportunities. Although the activities were applied to the whole group, the data were collected from fifteen participants, selected because of their permanent attendance to the sessions.

The selection of these students for my research project was basically done because of their concern about the development of their listening skills and their preoccupation for improving that aspect in their EFL learning process. When selecting the participants, I also took into consideration the fact that, before the project was implemented, scarcely did they have the opportunity to reflect upon their listening practices, and therefore, the feedback provided was minimum. Likewise, when the students were asked about new methods to be evaluated, all of them pointed out that more interaction and participation should be promoted in the exercises conducted.

\section{Phases of the Implementation}

\section{Knowing What Students Wanted}

The first stage for the implementation of the project was based on the exploration. Thus, before planning the stages of the study, I received some feedback from the participants after they took the tests the university demands. Through this feedback, I realized that they felt very uncomfortable with the way their listening skills were being developed. They pointed out that barely did they have the chance to reflect upon their process, or know what they needed to do to improve their audio comprehension skills. Likewise, they stated that other type of activities should be designed in order to promote more interaction and reflection upon the understanding of EFL audio recorded material. Once I knew what their interests were, I went on reading relevant literature dealing with the constructs I proposed in order to have solid theoretical support for the design and the application of the activities. 


\section{Implementation of the Activities}

In the implementation stage, I collected data by using three different instruments: journals, interviews and students' samples of the activities conducted. There were eleven sessions or activities beginning on October $24^{\text {th }}$ until November $23^{\text {rd }}$. Each of them took around 25 minutes and was divided in three steps. The next chart illustrates the dates and the topics that were covered in the activities. It is important to clarify that the activities were designed based on the topics the students were studying. It means that as I conducted the activities, the students advanced in the development of the program too.

\begin{tabular}{|c|c|c|}
\hline DATE & TITLE & ACTIVITIES \\
\hline October $24^{\text {th }}$ & "Feedback Session" & $\begin{array}{l}\text { Listening to the students' feelings } \\
\text { towards the presentation of the } \\
\text { listening exam, as well as their } \\
\text { perceptions about the development of } \\
\text { the listening skill. }\end{array}$ \\
\hline October 25th & "My Unlucky day" & $\begin{array}{l}\text { Understanding the description of an } \\
\text { unlucky day. Organising the order of } \\
\text { events. }\end{array}$ \\
\hline November $1^{\text {st }}$ & "Talented Children" & $\begin{array}{l}\text { Listening to a radio program about } \\
\text { talented children. Understanding } \\
\text { general and specific ideas. }\end{array}$ \\
\hline November 3rd & "Last Vacation" & $\begin{array}{l}\text { Listening to the description of a } \\
\text { person's vacation time. Matching } \\
\text { pictures with events. }\end{array}$ \\
\hline November $8^{\text {th }}$ & "Listening to the News" & $\begin{array}{l}\text { Understanding radio news. } \\
\text { Answering questions about the } \\
\text { material used }\end{array}$ \\
\hline November $9^{\text {th }}$ & "William Shakespeare" & $\begin{array}{l}\text { Watching a video about } \\
\text { Shakespeare's life. Completing the } \\
\text { corresponding video guide }\end{array}$ \\
\hline November $10^{\text {th }}$ & "Two Different Schools" & $\begin{array}{l}\text { Establishing differences between } \\
\text { two different schools. Making } \\
\text { comparisons and inferring } \\
\text { information. }\end{array}$ \\
\hline November $14^{\text {th }}$ & "Bartering" & $\begin{array}{l}\text { Listening and understanding a } \\
\text { lecture about bartering. Capturing } \\
\text { general and specific information on } \\
\text { the lecture. }\end{array}$ \\
\hline
\end{tabular}




\begin{tabular}{|l|l|l|}
\hline November $17^{\text {th }}$ & "Plans for Vacation" & $\begin{array}{l}\text { Listening to two speakers talking } \\
\text { about their plans for vacation, and } \\
\text { recognizing what those plans are. }\end{array}$ \\
\hline November 20 & "My Week..." & $\begin{array}{l}\text { Completing information about } \\
\text { one person's schedule. Identifying } \\
\text { specific information (days and times) }\end{array}$ \\
\hline November 23 & "Final Exam" & Presentation of students' final exam \\
\hline
\end{tabular}

The conduction of the activities was divided in two stages. In the first, the participants were familiarized with the material they would listen to. In this process, the participants related the background they had with the topic of the material. Thus, before listening to the material and performing the activities, the students already knew what the material was going to be about. Furthermore, the unknown vocabulary was sometimes clarified previously in order that the students could better understand the material provided. Basically, this step only consisted of doing some pre-listening tasks and did not last too long.

The second stage consisted of conducting the activity. After having familiarized the participants with the recordings, I carried on developing the activities I designed. It is important to highlight that the activities were piloted beforehand with another group, which was coursing the same level. In the development of the exercises, I only observed the way they went through the exercise, and I played the recording three or four times so that they had the opportunity to revise their answers. They were expected to do the activity individually since later on they had to reflect upon their own performance. Additionally, they did a process of self-correction and observed their right or wrong answers obtained all through the development activities.

\section{Performing Self-reflection Upon the activities}

In order to do this procedure, a journal was provided at the end of each activity. This journal contained some questions to be answered very objectively and some of them were changed or modified as the activities were being conducted. Furthermore, the questions had different objectives: some of them asked about their personal perceptions on the activity; others were related to language issues; and some others were about positive or negative insights they may have had. Those questions were designed with the purpose of reflecting upon the 
session they had just had. The participants were free to write and they could take their time to do it. Through the journal, they were expected to make a real and conscious self-assessment and reflective process. They spent usually around 10 minutes writing, and some of them found it difficult because they may not have been accustomed to do these kinds of exercises. However, all of them followed very satisfactorily the instructions and the steps given. As soon as they finished writing on the journals, they kept the records in their folders and then we did a brief closing of the activity. It means, we discussed about the material provided or talked about the difficulties or facilities they might have found in the sessions.

\section{Data Collection Procedures}

The data were collected by using three different instruments: Students' samples, journals and interviews. Regarding the samples, the participants were asked to keep the formats of the activities in a folder. In such formats, both the date and the name of the participant were written so as to systematize the information in such a way that the data analysis procedure was easier to achieve. The journals, on the other hand, followed a similar process. Once the participants filled them out, they had to keep them in their folders. Thus, the collection of the journals was organized according to the date and the activity. Finally, after the application of the activities the participants conducted a semi-structured interview so that freedom in the answers was promoted. Those data were textually transcribed in order to make a proper triangulation process with the other two instruments.

\section{Preliminary Data Analysis}

Even though talking about a complete data analysis is not accurate by this point of my research process, I have already carried out an exhaustive reading of the data collected. Likewise, I have identified some common patterns throughout the interviews and the journals. Those patterns will be described as follows:

\section{Language constraints}

Most of the participants coincide that language is an important factor that affects the understanding of EFL recorded material. According to their reflections in the journals, they find it very difficult to understand the material played, when for example; there is lack of vocabulary in the recordings. Even though some of the words were given in the glossary of the activities, the participants still believe 
that not knowing enough vocabulary disrupts the way their comprehension process is assimilated. Another language constraint might emerge from some processes the participants are not accustomed to: assimilation, linking process, pace and accent of the speakers, among others. Similarly, the participants state that when they listen to the material without the script, they do not identify the processes that actually occur in the recordings; however, when they see and follow the material with the script, it becomes much clearer and they can understand much more the recording.

\section{Lack of strategies and familiarization with the kinds of activities}

For almost all the participants the lack of strategies was present in the development of the first three activities. They point out that they did not feel comfortable with the exercises since they could not find the best strategy to achieve them. As a matter of fact, at the beginning of the project some of them felt a little frustrated because they noticed that their process did not advance as much as they expected. These conceptions are reflected in the journals and some interviews. However, as the activities were being developed some of the participants tried to use some strategies in order to overcome the difficulties they found in the activities. Furthermore, most of the participants believe that in spite of the fact that there was a prior familiarization with the material, sometimes it was not enough since they could not identify the general idea of the recording, and even less specific details.

\section{Positive insights on the application of the self-assessment procedures in the group}

Through the journals and the interviews, the participants agreed with the importance of applying and conducting self assessment practices. According to their perceptions, when they self-assessed their performance, they could have the opportunity to reflect on the weaknesses and strengths. Likewise, due to their inexperience with those practices, most of them consider that it is a new process which could be applied in the current program designed by the institution. They also think that when they evaluate their process, they can identify and work on the constraints they encounter.

\section{Progress in their comprehension process of EFL recorded material}

Although at the beginning of the project it was difficult for many of them, the participants also agree in that their process of understanding EFL recorded 
material actually improved. They also believe that they overcame many of the difficulties they had before the application of the project. (Insecurity, predisposition to the activities, frustration, among others) In other words, they found really useful the fact that they had evaluated their own performance since; thus, they could know exactly what the problem was and look for an adequate solution for the following activity.

\section{My experience in the development of the project}

In spite of the fact that the project has not been finished yet, I could say that the experience of applying these practices have been beneficial both for my personal and my professional growth. In the personal aspect because I learnt to be much more sensitive with the people I teach, I learnt that they face a lot of difficulties in their process, and I learnt to understand that sometimes we, teachers, might be wrong. Also, I was able to document many of the fears; sentiments and perceptions students have towards our teaching practices. Finally, I learnt that teaching does not only consist of boards, papers and markers. On the contrary, it needs to be addressed to team work, interaction and reflection from teachers, learners, and all those involved in the language education field. For my professional growth the experience of having conducted research taught me a lot about the necessity of analysing the constraints the process of teaching and learning English might have. We, as teachers, need to understand that our practices should go beyond the mere action of transmitting knowledge; in turn, our practices ought to be focused on a permanent analysis about what and how we are teaching, and what is it that we have to change in order to assure proper and effective teaching procedures.

\section{References}

Boyle, E. (1993). An alternative approach to improving listening skills. English Teaching Forum. Number 3, Volume 31-July. Located at Universidad Distrital

White, G. (1998). Listening. Oxford University Press.

Cohen, A. (1994) Key Questions in language assessment. Assessment Language Ability in the classroom. P 11-48. Heinle and Heinle. U.S.A

Boston, Carol. (2002). The Concept of formative assessment. Practical assessment: Research and Evaluation. Internet document downloaded from http://PAREonline.net 
Brualdi, Amy. (1998). Implementing performance assessment in the classroom. Practical Assessment: Research \& Evaluation. Internet document downloaded from http:// PAREonline.net

O'Malley and Valdez. (1996). Authentic Assessment for Language Learners. AddisonWesley Publishing.

Coombe, C. and Kinney J. Learner-Centred Listening Assessment. Eric Digests. Internet document downloaded from www.ericdigests.org.

Bell, J. (1999). Approaches to educational research. Doing Your Research Project. Philadelphia, U.S.A. Open University Press. Located at Universidad Distrital 


\section{Appendix 1}

\section{Consent form for students}

Bogotá, Septiembre 25 de 2006

Señores: Estudiantes Bàsico II -Centro Lenguas Universidad Pedagògica Nacional-

El presente comunicado es con el fin de informarles que me encuentro cursando la Maestría en Lingüística Aplicada para la enseñanza del Inglés de la Universidad Distrital Francisco José de Caldas, y actualmente estoy trabajando mi tesis de grado bajo el nombre "The Role of New Self-Assessment Listening Practices at a Public University" (El Papel de Nuevas Prácticas de Auto-Evaluación de la habilidad de Escucha en una Universidad Pública). El proyecto busca examinar la manera cómo la implementación de nuevas prácticas, basadas en la Auto-Evaluación por parte de los estudiantes, influyen en el desarrollo de la habilidad de escucha en el proceso de aprendizaje del inglés. Asimismo, se busca analizar las percepciones de los participantes en relación con la implementación de dichas prácticas en su proceso de aprendizaje. Esta investigación contribuirá en primera instancia a desarrollar nuevos sistemas de evaluación de la habilidad de escucha en el centro; y por otra parte, a motivar al estudiante a que participe más activamente en procesos críticos de auto-evaluación, con miras a mejorar Ios resultados en su proceso de aprendizaje del inglés como lengua extranjera.

La recolección de datos para el proyecto se hará durante el presente semestre académico, contando previamente con su aprobación y participación. Dicha recolección incluye toma de muestras (entrevistas, muestras de las actividades y reflexiones de los participantes). Solicito a ustedes su participación dentro del proyecto, pues es de vital importancia para mi quehacer como investigador, y además contribuye al desarrollo académico del Centro. A todos los participantes se les garantizará:

1. El uso de nombres ficticios para mantener su identidad en el anonimato.

2. Estricta confidencialidad con la información que se recolecte.

3. La oportunidad de verificar los datos recolectados en el borrador de los informes del proyecto.

4. Que el proyecto no tendrá incidencia alguna en las evaluaciones y notas parciales y/o finales del nivel que están cursando.

5. La opción de retirarse de la investigación si así lo consideran conveniente.

Agradezco de antemano su colaboración y atención para esta solicitud.

Cordialmente,

FIRMA

NOMBRE 


\section{Appendix 2}

\section{Students' Journal}

NAME DATE

1. ¿Cómo te sentiste en la actividad de hoy? explica tu respuesta.

2. ¿Hasta qué punto crees que las dificultades evidenciadas en las actividades anteriores se han superado?

3. ¿Crees que mejoraste en esta actividad? ¿De qué manera?

4. ¿Te sientes satisfecho (a) con tu desempeño en esta actividad? ¿Por qué?

5 ¿Tuviste alguna dificultad en el desarrollo de esta actividad? ¿Cuál? 


\section{Appendix 3}

\section{Interview}

El propósito de la siguiente entrevista es conocer sus opiniones sobre el proyecto de investigación que se está llevando a cabo actualmente. Por favor, responda las siguientes preguntas de la manera más objetiva posible, teniendo en cuenta la manera como usted ha percibido la aplicación de las actividades.

- En líneas generales, ¿cómo se ha sentido en el desarrollo de las actividades del proyecto? Explique su respuesta y tenga en cuenta el proceso que se ha realizado en cada una de ellas

- ¿En su opinión, hasta qué punto considera que las actividades que se han realizado han favorecido su proceso de comprensión auditiva de material en inglés?

- ¿Cómo se ha sentido en el momento de auto-evaluar su proceso de comprensión auditiva en las actividades realizadas? Explique su respuesta.

- ¿Cree usted que el hecho de auto-evaluar su desempeño en las actividades de escucha propuestas para el proyecto ha tenido alguna incidencia en el desarrollo de su habilidad auditiva? ¿Por qué?

- ¿Ha encontrado algún tipo de dificultad en el desarrollo de las actividades? ¿Cuál (es)?

- ¿Haría alguna sugerencia para futuras aplicaciones de este proyecto u otro similar?

\section{THE AUTHOR}

Edgar Orlando Rodríguez Ochoa, M.A Candidate in Applied Linguistics to the TEFL., B.A in Modern Languages (Spanish and English) from Universidad Pedagógica Nacional. Experienced on tertiary education institutions. He is currently working at Minuto de Dios University and at the Languages Center of the Universidad, Pedagógica Nacional as an English teacher. E-mail:0r001co@yahoo.com 